(2) OPEN ACCESS

\title{
Priority setting and personal health responsibility: an analysis of Norwegian key policy documents
}

\author{
Gloria Traina 조 , Eli Feiring $($ )
}

- Additional material is published online only. To view please visit the journal online (http://dx.doi.org/10.1136/ medethics-2019-105612).

Department of Health Management and Health Economics, University of Oslo, Oslo, Norway

\section{Correspondence to} Gloria Traina, Department of Health Management and Health Economics, University of Oslo, Oslo 0317, Norway; gloria.traina@medisin.uio.no

Received 5 June 2019 Revised 11 February 2020 Accepted 17 February 2020

\section{Check for updates}

(C) Author(s) (or their employer(s)) 2020. Re-use permitted under CC BY-NC. No commercial re-use. See rights and permissions. Published by BMJ.

To cite: Traina G, Feiring E. $J$ Med Ethics Epub ahead of print: [please include Day Month Year]. doi:10.1136/ medethics-2019-105612

\section{ABSTRACT}

Background The idea that individuals are responsible for their health has been the focus of debate in the theoretical literature and in its concrete application to healthcare policy in many countries. Controversies persist regarding the form, substance and fairness of allocating health responsibility to the individual, particularly in universal, need-based healthcare systems.

Objective To examine how personal health responsibility has been framed and rationalised in Norwegian key policy documents on priority setting.

Methods Documents issued or published by the Ministry of Health and Care Services between 1987 and 2018 were thematically analysed $(n=14)$. We developed a predefined conceptual framework that guided the analysis. The framework included: (1) the subject and object of responsibility, (2) the level of conceptual abstraction, (3) temporality, (4) normative justificatory arguments and (5) objections to the application of personal health responsibility.

Results As an additional criterion, personal health responsibility has been interpreted as relevant if: (A) the patient's harmful behaviour is repeated after receiving treatment (retrospectively), and if (B) the success of the treatment is conditional on the patient's behavioural change (prospectively). When discussed as a retrospective criterion, considerations of reciprocal fairness have been dominant. When discussed as a prospective criterion, the expected benefit of treatment justified its relevance.

Conclusion Personal health responsibility appears to challenge core values of equality, inclusion and solidarity in the Norwegian context and has been repeatedly rejected as a necessary criterion for priority setting. However, the responsibility criterion seems to have some relevance in particular priority setting decisions.

\section{INTRODUCTION}

The idea that individuals are responsible for their health has been frequently discussed in the academic literature on public health ethics and particularly with regard to fair allocation of scarce healthcare resources. ${ }^{1-8}$ Appeals to personal health responsibility have further attracted the attention of policymakers. European countries such as the UK, Sweden and Germany, as well as Medicaid programmes in some US states, have developed policies that rely on individuals being able to take responsibility for their own health and, to some extent, hold people responsible for health outcomes. ${ }^{9-13}$

These policies may take various forms. Many prevention policies aim at changing individual health-related behaviour to lessen the burden of lifestyle diseases, emphasising the importance of responsible agency. ${ }^{14}$ In clinical settings, patients may be asked to make lifestyle changes in order to qualify for treatment, for instance by making surgery conditional on smoking cessation or weight loss, as proposed in the UK. ${ }^{15}$ Furthermore, recent policy proposals in Germany and Sweden have suggested that patients may be given lower priority on waiting lists or be requested to pay greater financial contributions when deemed responsible for their healthcare needs. ${ }^{10} 16$ The introduction of policies that require people to use their personal resources, or that establish conditional access to healthcare based on health-related behaviour, is of particular interest for countries with universal and tax-based healthcare. In these settings, citizens traditionally expect to receive care when health needs arise, regardless of the cause of the disease. However, as the burden of lifestyle diseases increases and economic circumstances change, a reconfiguration of the scope and content of services covered may seem appealing to policymakers. ${ }^{17}$

This study aimed to investigate how the idea of personal health responsibility has been framed, rationalised and discussed in key policy documents on priority setting in Norway.

\section{Conceptual framework: personal health responsibility}

The concept of personal health responsibility may acquire different meanings depending on the context and the substance of its application. ${ }^{8}$ For the purpose of this study, health responsibility was understood as a multidimensional concept. Based on refs $237-22$, we synthesised and developed a conceptual framework to aid the analysis of personal health responsibility, constituted by five dimensions (figure 1).

The dimensions included: (1) the moral subject and object of responsibility, (2) the level of conceptual abstraction, (3) temporality and (4) normative justificatory arguments. In addition, we included a dimension that systematises the objections to the application of personal health responsibility (5).

The moral subject and object of health responsibility Central to an analysis of health responsibility is the question of who is responsible (moral subject) for what (moral object). ${ }^{418} 19$ At the individual level, it is commonly thought that only individuals possessing the capacity to evaluate reasons for acting are suited to responsibility ascriptions. ${ }^{23}$ At the collective level, society can be the subject of moral health responsibility in the form of being attributed an obligation to provide access to healthcare for its citizens ${ }^{24}$ and to promote population health through preventive medicine, research and 


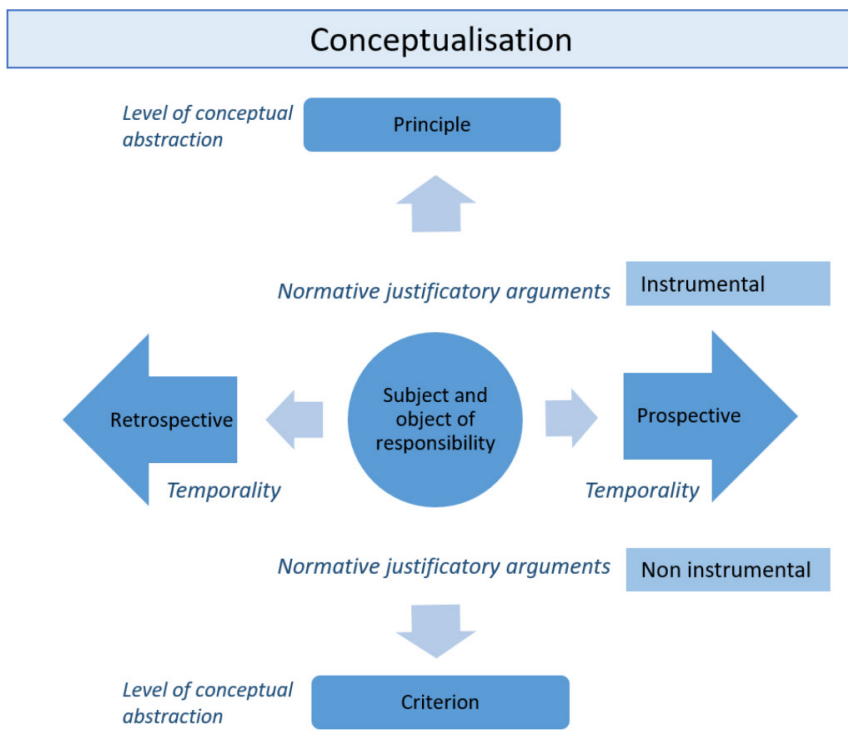

\section{Application}

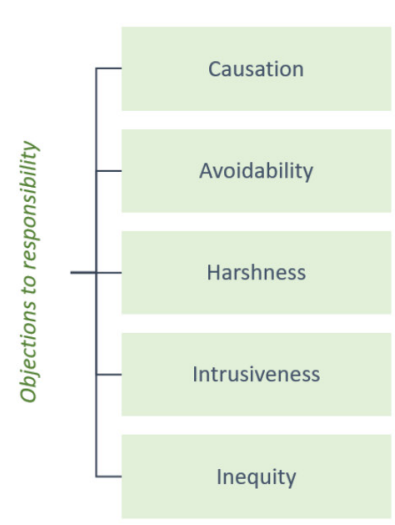

Figure 1 Conceptual framework for the thematic analysis.

environmental policies. ${ }^{25} 26$ The objects of responsibility are multiple and can refer to actions, omissions or consequences. ${ }^{19}$

\section{The level of conceptual abstraction}

The level of conceptual abstraction distinguishes between understandings of personal health responsibility as a principle or criterion. While principles are broad statements of objectives, such as general directives of what to do, criteria specify conditions that need to be met to adhere to a principle and are used as standards for evaluation and judgement. ${ }^{27}$

The dimension of conceptual abstraction allows differentiating between general and specific attributions of personal responsibility for health. For example, appeals to personal responsibility for health could be seen as moral or spiritual duties to oneself and to society to maintain physical and mental well-being. In this case, personal responsibility is an idealised principle that does not imply specific rationing decisions. ${ }^{20}$ In other cases, however, the person's responsibility for past or future behaviour could be applied as a criterion for the assessment of eligibility to services. This can result in exclusion from certain types of treatment, higher copayments or lower priority in access to healthcare.

\section{Temporality}

Retrospective forms of responsibility can be ascribed when the individual's past actions are identified as the main cause of a present outcome (factual causal responsibility) or because of the individual's distinctive place in social life, which conveys duties and obligations that the individual has not fulfilled (role responsibility). ${ }^{82}$ For example, it has been discussed whether patients who in the past have engaged in harmful behaviours (eg, smoking) have an equal right and priority to treatment for lifestyle-induced diseases. ${ }^{29} 30$

Prospective approaches consider the responsibility of the individual for behaviour that has future health-related consequences. This forward-looking personal health responsibility is commonly understood as an encouragement to take responsibility for one's health, aiming at raising awareness of the consequences of harmful behaviour. ${ }^{31}$ For instance, the responsibilisation of the individual can include the implementation of policies that facilitate healthy choices, such as health education and the taxation of harmful substances. Policies prescribing lower priority or higher copayments for lifestyle diseases may also be implemented as deterrence policies, as the prospect of this future risk is thought to have the effect of discouraging individuals from engaging in harmful behaviours. ${ }^{32}$ Prospective health responsibility at the clinical level can also entail the stipulation of contracts between the patient and the healthcare provider, which clarifies the expectations and requirements that must be fulfilled to be eligible for treatment. ${ }^{733}$

Normative justificatory arguments

This dimension is constituted by the normative standards of reference that can justify the attribution of personal responsibility for health. ${ }^{19}$ Personal responsibility for health may be justified based on normative frameworks that include views of fairness, equality and autonomy, that is, non-instrumental justifications. ${ }^{23435}$ For example, appeals to personal health responsibility may be grounded in the social contract of rights and obligations that citizens may legitimately expect each other to fulfil. In this view, individual choices may have obligation-shifting power. ${ }^{36}$ Another example is choice-sensitive forms of egalitarianism such as luck-egalitarianism, which holds that inequalities that are a result of 'brute luck' should be compensated by public institutions, while inequalities that are a product of 'option luck' (through no fault or choice of one's own) are not viewed as unfair. $^{7037-39}$ Attributing personal responsibility can also stimulate autonomy and self-determination by respecting personal voluntary choices and preferences. ${ }^{35}$ An alternative normative approach is the one compatible with consequentialist theories (ie, instrumental justifications), by which the moral rightfulness of actions is decided by the optimality of its consequences. ${ }^{40}$ If a principle or criterion of personal health responsibility brings about better health outcomes, for example, because individual choices can be influenced or because the expected effect of treatment can be improved, it may be endorsed on consequentialist grounds. $^{230384142}$

\section{Objections to responsibility attributions}

The idea that individuals are responsible for their actions and behaviour has been the subject of theoretical discussions involving the plausibility of free will, the conditionality of voluntariness and the definition of the boundaries to individual freedom. ${ }^{20}$ These fundamental metaphysical issues, together with empirical evidence on the social determinants of health, ${ }^{43}$ as well as 
findings from neuropsychology on the role that conscious choice plays in our actions, ${ }^{44}$ question whether individuals can be the subjects of responsibility attributions altogether. These questions are at the root of two main objections to personal responsibility for health. First, one of the conditions for being able to attribute responsibility to somebody for something is that the subject of responsibility has acted freely and could have done otherwise at the time of the action. ${ }^{23}$ The avoidability objection claims that for many health-related behaviours, the condition of voluntary and full-informed choice is not satisfied. For instance, substance addiction, the inability to understand health information and numerous socioeconomic factors set constraints on lifestyle choices. ${ }^{45}$ Second, the actions and behaviours of the individual must be the actual cause of ill health. ${ }^{23}$ Given the importance of exogenous contributing factors beyond individual control, such as genetic predispositions and biological factors, the causation objection explains why determining the extent to which the patient's healthcare needs are caused by lifestyle is difficult. ${ }^{21} 4246$

Other objections concern the practical implementation of personal health responsibility. The harshness objection states that it would be too harsh to make treatment conditional on the individual's own health responsibility because the public has a moral obligation for taking care of individuals in need even when the illness is perceived as self-inflicted. ${ }^{21} 2247$ The intrusiveness objection points to the fact that the process of ascription of responsibility may be experienced as an invasion of the individual private sphere that could bring about feelings of shame and distrust. ${ }^{21}{ }^{2642}$ Finally, given the relationship between socioeconomic status and health-related behaviours, ${ }^{43}$ the inequity objection holds that the attribution of personal health responsibility could disproportionately harm the worst-off, reinforcing inequities. ${ }^{26}$ This objection is based on empirical studies of the distribution of unhealthy lifestyles in populations, showing socioeconomic gradients in clusters of health-related behaviours.

\section{METHODS}

\section{Study design}

This study was designed to be a qualitative document analysis. This type of research entails the processes of finding, selecting, interpreting and synthesising data contained in documents. The data obtained (eg, excerpts, quotations or passages) were organised into major themes through thematic analysis to develop empirical knowledge. ${ }^{48} 49$ Data gathering and analysis were conceptually driven and based on the framework illustrated in figure 1.

\section{Study setting}

The Norwegian welfare state is rooted in the principles of equality, inclusion and solidarity, ${ }^{50}$ and the healthcare system is universal and tax-financed. Norway has a long history of public debate on healthcare priority setting, starting in the 1980s. Today, the Patient and User Rights Act establishes the legal right to equal access to healthcare services for all residents. ${ }^{51}$ According to the Specialist Healthcare Act, the regional health authorities have the responsibility of providing specialist care to the residents of each region. The provision of specialist care shall be regulated by three priority setting criteria: the health benefit of the medical intervention, the cost-effectiveness of the intervention and the severity of the medical condition. ${ }^{52}$

\section{Data sources}

We wanted data on (1) the preparatory stage of the policy process and (2) policy formulation. All Norwegian Official
Table 1 Keywords used to identify relevant text sections across all documents

\begin{tabular}{ll}
\hline English & Norwegian \\
\hline Personal responsibility & Personlig ansvar \\
\hline Individual responsibility & Individets ansvar \\
\hline Self-responsibility & Egenansvar \\
\hline Health-related behaviour & Helseatferd \\
\hline Lifestyle & Livsstil \\
Willingness to cooperate & Samarbeidsvilje \\
\hline Self-inflicted & Selvforskyldt \\
\hline Health-related choices & Helsevalg \\
\hline Individual effort & Egeninnsats \\
\hline
\end{tabular}

Reports (NOUs) $(\mathrm{n}=7)$ and a report $(\mathrm{n}=1)$ on priority setting commissioned or published by the Ministry of Health and Care Services were included in the analysis. The NOUs resemble a hybrid of British Green Papers and commissioned reports. ${ }^{53}$ The reports are written by ad hoc advisory commissions appointed by the government to examine major policy issues and to suggest possible solutions for policymaking. Both experts and laypeople participate in these commissions. ${ }^{54}$ The reports have an important role in the formulation of Norwegian public policy and serve the need to back up political proposals with references to research and to integrate interest groups in the policy process. The reports are followed by White Papers (Stortingsmeldinger), in which concrete policies are proposed by the government. We included the White Papers that followed the reports on priority setting $(n=6)$. The year of publication was used to determine the time frame of the analysis: the first NOU on priority setting was published in 1987, and the last NOU in 2018 (bibliographical information reported in online supplementary appendix A).

\section{Data analysis}

The documents were analysed in NVivo 12 in two rounds. First, a search of keywords to identify text sections that concerned the conceptualisation of personal health responsibility was conducted (table 1). Text units were sorted into themes and subthemes given by our conceptual framework.

Second, the objections to the application of personal responsibility were identified and systematised into the relevant categories. The process was discussed and reviewed by both authors to ensure consistency and reliability. Illustrative quotes were translated from Norwegian to English by the first author.

\section{RESULTS}

The document analysis suggests that personal health responsibility has been framed and rationalised consistently over time, regardless of shifting political powers, economic and technological progress and academic developments in healthcare prioritisation.

\section{The conceptualisation of personal health responsibility}

The document analysis shows that personal health responsibility was repeatedly interpreted as a criterion of individual accountability intended to regulate substantial decisions on whether patients should 'be held responsible' when determining their eligibility for treatment. The conceptualisation had patients as subjects of responsibility and concerned their health-related behaviour, their health impairment and their own individual efforts in dealing with the disease. The criterion was framed as a 
contested criterion for priority setting decisions, ${ }^{55-59}$ that is, an additional criterion that 'should not be given independent weight in priority setting decisions' (p. 110) ${ }^{59}$, and furthermore, 'had to be subordinated to the necessary criteria of severity, healthbenefit and cost-effectiveness' (p. 78). ${ }^{58}$

The criterion was found both in a retrospective and a prospective version. In its retrospective version, the criterion was discussed as 'the patient's possible self-responsibility for the occurred problem' (p. 85$)^{60}$ with regard to 'the question of whether self-inflicted health impairment should have priorityrelated consequences for the individual patient' (p. 86) ${ }^{60}$ For example, the patient's responsibility for past lifestyle was brought up under the discussion of the application of co-payments to healthcare services. ${ }^{61}$

In the initial discussions of the relevance of personal health responsibility for priority setting, the retrospective attribution of responsibility was rejected as a necessary criterion. This standpoint was reaffirmed in later documents. ${ }^{55} 5762$ However, the criterion was found to be appropriate in decisions considering cases of reiteration of harmful behaviour. In these cases, reciprocal fairness seemed to justify its use:

It would be unreasonable to repeat treatment for notoriously selfinflicted diseases and injury in cases where it is clear that the patient overlooks the information and guidance or directly opposes the advice provided as a prerequisite for the treatment. (p. 13) ${ }^{60}$

Evaluating the patient's willingness to change lifestyle or behaviour as an additional criterion in priority setting decisions was repeatedly discussed in the reports and White Papers. The criterion could be included in 'the discretionary prioritisation decisions at the clinical level' (p. 12). ${ }^{57}$ This prospective version of the criterion was mainly justified with reference to the consequences for the treatment success of the behavioural change. Yet, we also found a reference to prospective responsibility justified by the respect for autonomous choice, citing 'the value of the individual retaining control and taking responsibility for her own existence' (p. 25). ${ }^{63}$

Table 2 summarises the results of the thematic analysis on the conceptualisation of personal health responsibility.

Objections to the application of personal health responsibility At the same time, several objections to the relevance of personal responsibility in priority setting were discussed in the documents. For example, the report of $1987^{60}$ emphasised that to attribute personal responsibility to the individual patient, 'there ought to be a proven causal relationship between the patient's behaviour and lifestyle and the diagnosed illness or injury' ( $\mathrm{p}$. $85) .{ }^{60}$ In addition to the causation objection, challenges related to the objection of avoidability (the extent to which the individual was informed about the consequences of her behaviour and whether she could have acted differently) were considered:

Many among today's smokers were smokers for decades before they could have known that smoking increased the risk for lung cancer and other diseases. The same could be said about the relationship between diet, lifestyle and cardiovascular diseases. (p. 85$)^{60}$

Table 2 Results for the subthemes regarding the conceptualisation of personal health responsibility

\begin{tabular}{|c|c|c|c|}
\hline Sub-themes (i) & Subthemes (ii) & $\begin{array}{l}\text { Identified understandings of } \\
\text { personal health responsibility }\end{array}$ & Illustrative quotes \\
\hline \multirow{2}{*}{$\begin{array}{l}\text { Subject of } \\
\text { responsibility }\end{array}$} & Individual citizen & - & - \\
\hline & Patient & Patient & 'The patient's possible self-responsibility for the occurred problem' (p. 85). ${ }^{60}$ \\
\hline \multirow[t]{3}{*}{$\begin{array}{l}\text { Object of } \\
\text { responsibility }\end{array}$} & $\begin{array}{l}\text { Health-related } \\
\text { behaviour }\end{array}$ & Harmful behaviour & $\begin{array}{l}\text { 'A lifestyle that reduces the effect of an intervention (...) can be included in the discretionary } \\
\text { prioritisation decisions at the clinical level' (p. 12). } .^{57}\end{array}$ \\
\hline & & Individual effort & $\begin{array}{l}\text { 'The expected individual effort should be given weight (...) This applies particularly to } \\
\text { responsibility for own physical training, as for patients with inflammatory rheumatic diseases } \\
\text { and lung disorders, and lubrication, as for patients with skin disorders' (p. 86). }{ }^{58}\end{array}$ \\
\hline & Health state & Health impairment & $\begin{array}{l}\text { 'The question of whether self-inflicted health impairment should have priority-related } \\
\text { consequences for the individual patient' (p. 86). }{ }^{60}\end{array}$ \\
\hline
\end{tabular}

\begin{tabular}{lll}
$\begin{array}{ll}\text { Level of conceptual } \\
\text { abstraction }\end{array}$ & $\begin{array}{l}\text { Principle } \\
\text { Criterion }\end{array}$ & $\begin{array}{l}\text { Contested criterion } \\
\end{array}$ \\
\hline Temporality & Retrospective & Self-infliction
\end{tabular}

'There are many criteria that belong to the group with more contested criteria (...) such as (...) self-infliction and willingness to cooperate' (p. 61)..$^{55}$

' $(T)$ he question of self-responsibility for illness is relevant when assessing whether or not there should be a co-payment. One could imagine that those who themselves are responsible for their illness must pay more for the services' (p. 42). ${ }^{61}$

'It is a distinct problem when one who has benefited from scarce and costly resources (...) continues to jeopardise her health by maintaining a detrimental lifestyle despite information and advice' (p. 85). ${ }^{60}$

Prospective Willingness to cooperate

'It is not justifiable to undertake extensive and risky procedures if the patient is not prepared to make the changes in (his/her) living habits which under any circumstance will be a condition for a satisfactory outcome of treatment' (p. 86). ${ }^{60}$

\begin{tabular}{|c|c|c|}
\hline \multirow[t]{3}{*}{$\begin{array}{l}\text { Normative } \\
\text { justificatory } \\
\text { arguments }\end{array}$} & Non-instrumental & $\begin{array}{l}\text { When justified with reference to } \\
\text { reciprocal fairness }\end{array}$ \\
\hline & & $\begin{array}{l}\text { When justified with reference to } \\
\text { autonomy }\end{array}$ \\
\hline & Instrumental & $\begin{array}{l}\text { When justified with optimisation } \\
\text { of expected benefit }\end{array}$ \\
\hline
\end{tabular}

'(T)here will be strong (...) arguments for the health service to be reluctant to use the same scarce and costly resources to repeat the treatment of the same disease. The argument that other patients on the same waiting list, being sick through no fault of their own, should be prioritised, will in such a case easily be regarded as fair' (p. 85). ${ }^{60}$

'(A patient) that is not willing to accept help to stop the harmful behaviour (...) should not be prioritised' (p. 132). ${ }^{57}$

'(T)he expected benefit of a measure (can) depend on whether the patient changes his lifestyle or changes behaviour. If this is the case, it would be natural for healthcare professionals to take this into account in the clinical assessment of the expected benefit of treatment ${ }^{\prime}(p .107){ }^{59}$ 
Also, it was pointed out that individuals with less education have worse access to health information and the avoidability of harmful behaviours for the least advantaged was questioned. ${ }^{61}$ Objections of avoidability were furthermore identified in a prospective version. Discussing the relevance of the patient's 'willingness to cooperate', it was concluded that a lack of cooperation from the patient could be due to a lack of good communication in the patient-doctor interface, thus weakening the claim that the patient made an informed choice not to comply with the doctor's advice. ${ }^{62}$

Furthermore, a reluctance to include a responsibility criterion when determining eligibility to healthcare was grounded in arguments about harsh consequences: 'No one should be denied treatment because the condition is due to negligent or reckless behaviour' (p. 132). ${ }^{57} \mathrm{~A}$ responsibility criterion 'would not be accepted because it violates the principle of solidarity' (p. 92). ${ }^{57}$ To deny individuals necessary treatment would also infringe on the respect for human dignity and inclusion central to the healthcare system, as 'one can easily end up with an unfortunate distinction between the "worthy" and the "unworthy" in relation to health and social services' (p. 42) ${ }^{61}$ In particular, considerations of equity played an important role: 'a negative criterion (ie, exclusion from benefits) can have an unfortunate systemic effect in the sense that the healthcare system reinforces inequality in socio-economic status' (p. 57). ${ }^{62}$

Three recent documents on priority setting ${ }^{63-65}$ touched on the issue of personal health responsibility only briefly, or not at all. This finding may signify that the responsibility criterion has had marginal relevance in the Norwegian priority setting debate of the last few years. Yet, in the most recent White Paper on priority setting, the responsibility criterion was once again discussed and dismissed as a decisive criterion for prioritisation. ${ }^{59}$ Table 3 summarises the results of the thematic analysis on the application of personal health responsibility.

\section{DISCUSSION}

Personal responsibility for health has been framed as a contested criterion in Norwegian key policy documents on priority setting. Our analysis suggests that justifying such a criterion on consequentialist arguments (such as health gain maximisation) appears to be less controversial in the Norwegian context than adopting arguments of reciprocal fairness; the criterion could be relevant for decisions on resource allocation when personal responsibility is expected to be instrumental for the success of the treatment. However, non-instrumental rationales were given some weight in the debate. Despite the general reluctance to apply the criterion of individual accountability retrospectively, cases of repeated self-infliction were identified in the data as situations where the patient's responsibility may become relevant.

Our analysis suggests that policymakers have delegated the difficult decision on when to attribute relevance to personal responsibility to those working at the 'bedside'. A pertinent rationale for this delegation is that the medical personnel interact with patients first-hand, having the opportunity to gather the necessary information to make such difficult decisions. However, there is a risk that this may create a grey zone between medicine and morality, which leaves, on the one hand, the doctors in charge with a major ethical dilemma and, on the other hand, opens the possibility for mechanisms of arbitrariness that can undermine equality in access to care. Prior research points out that medical staff may take moral judgements into account, consciously or not, unless discouraged to do so by the organisational norms surrounding them. ${ }^{66}$

A more thorough discussion of what 'to take responsibility for own health' actually implies, together with an articulation of how personal responsibility in health is complementary or supplementary to social responsibility, is thus warranted. We suggest that further theoretical and empirical work on the relevance of personal health responsibility for priority setting decisions should pay more attention to the element of repetition of behaviour. This element seems to matter, but attempts at systematically addressing its significance have been limited (but see Bærøe and Cappelen ${ }^{21}$ and Brudney ${ }^{67}$ ).

There are a few limitations to this study. First, we did not take into consideration the political, historical and economic context surrounding each document, and we did not analyse the political debates in parliament that followed each White Paper. These choices were necessary given the amount of data that could be analysed within this study but may have limited our analysis. Second, we applied a predefined framework to analyse the written material. By only identifying the themes included in this framework, we may have left out important nuances detectable through an inductive approach. Third, transferability of the Norwegian case to other health systems might

Table 3 Results for the subthemes regarding the objections to personal health responsibility

\begin{tabular}{|c|c|c|c|}
\hline Subthemes (i) & Subthemes (ii) & $\begin{array}{l}\text { Identified objections to } \\
\text { personal health responsibility }\end{array}$ & Illustrative quotes \\
\hline \multirow[t]{5}{*}{$\begin{array}{l}\text { Objections to } \\
\text { responsibility }\end{array}$} & Causation & $\begin{array}{l}\text { Evaluation of factual (not only } \\
\text { statistical) causal relationship }\end{array}$ & $\begin{array}{l}\text { '(T)here ought to be a proven causal relationship between the patient's behaviour and lifestyle and } \\
\text { the diagnosed illness or injury' (p. } 85){ }^{60}\end{array}$ \\
\hline & Avoidability & $\begin{array}{l}\text { Evaluation of earlier knowledge } \\
\text { and possibilities }\end{array}$ & $\begin{array}{l}\text { 'Many among today's smokers were smokers for decades before they could have known that } \\
\text { smoking increased the risk for lung cancer and other diseases. The same could be said about the } \\
\text { relationship between diet, lifestyle and cardiovascular diseases' (p. 85). }{ }^{60}\end{array}$ \\
\hline & Harshness & $\begin{array}{l}\text { Reluctance to deny necessary } \\
\text { treatment to those in need }\end{array}$ & $\begin{array}{l}\text { '(N)ot even the drunken reckless driver who smashes his car and himself into the mountain wall is } \\
\text { denied first aid or other necessary treatment and rehabilitation' (p. } 85){ }^{60} \\
\text { '(...) the central political currents in Norway for the last hundred years have generally aimed } \\
\text { at opposing to such principles (ie, desert-based) for the distribution of benefits. The principle of } \\
\text { distribution according to desert seems to be stronger in its negative version: that someone is } \\
\text { excluded from benefits because they have done something, or neglected to do something, implying } \\
\text { that they do not deserve (those benefits). A key concept here is lifestyle-related diseases' }(p .75) .{ }^{60}\end{array}$ \\
\hline & Intrusiveness & - & - \\
\hline & Inequity & $\begin{array}{l}\text { Risk of reinforcing socioeconomic } \\
\text { inequity in access to healthcare }\end{array}$ & $\begin{array}{l}\text { 'A negative criterion (ie, exclusion from benefits) can have an unfortunate systemic effect in the sense } \\
\text { that the healthcare system reinforces inequality in socio-economic status' (p. 57). }{ }^{62}\end{array}$ \\
\hline
\end{tabular}


be a challenge, given the specific egalitarian context of Norwegian healthcare. The discussions and applications of a criterion of personal health responsibility could be less controversial in health systems with different ideological and cultural characteristics. We believe, however, that our findings are relevant to other healthcare systems challenged by an increasing burden of non-communicable diseases and limited healthcare resources.

\section{CONCLUSION}

The analysis indicates that personal responsibility for health understood as individual accountability has been framed as a contested criterion in the key policy documents on priority setting in Norway. Personal health responsibility was framed and rationalised consistently over time.

The discussion of personal health responsibility seems to be an element that policymakers cannot leave utterly outside of the debate on distributive justice in healthcare but is too controversial to be included in the regulatory framework on priority setting. Personal health responsibility had relevance as an additional criterion in priority setting decisions in two cases. In a retrospective version, if the harmful behaviour was repeated after receiving treatment, responsibility was understood as a criterion of self-infliction and justified with reference to noninstrumental arguments of reciprocal fairness. In a prospective version, understood as willingness to cooperate, consequentialist arguments of the expected benefit of treatment were put forth to justify personal health responsibility.

Several objections to the actual application of personal health responsibility in priority-setting policies were identified in the texts. The analysis indicates that the application of the idea that 'individuals are responsible for their health' to concrete policies of priority setting has been difficult to reconcile with the principles of equality, inclusion and solidarity characteristic of the Norwegian healthcare system.

Acknowledgements We would like to thank the two anonymous reviewers whose comments have greatly improved thismanuscript.

Contributors GT provided the conception and design of the study, selected the material, interpreted the findings and was responsible for drafting the manuscript and making substantial revisions in all phases. EF assisted the design of the study, assisted in the selection, analysis and interpretation of the material and revised the drafts substantially for important intellectual content. Both authors gave final approval of the version to be submitted.

Funding The authors have not declared a specific grant for this research from any funding agency in the public, commercial or not-for-profit sectors.

Competing interests None declared.

Patient consent for publication Not required.

Provenance and peer review Not commissioned; externally peer reviewed.

Data availability statement Data are available upon request

Open access This is an open access article distributed in accordance with the Creative Commons Attribution Non Commercial (CC BY-NC 4.0) license, which permits others to distribute, remix, adapt, build upon this work non-commercially, and license their derivative works on different terms, provided the original work is properly cited, appropriate credit is given, any changes made indicated, and the use is non-commercial. See: http://creativecommons.org/licenses/by-nc/4.0/.

\section{ORCID iDs}

Gloria Traina http://orcid.org/0000-0003-1068-4509

Eli Feiring http://orcid.org/0000-0001-5280-1051

\section{REFERENCES}

1 Knowles J. The responsibility of the individual. Daedalus 1977:57-80.

2 Wikler D. Who should be blamed for being sick? Health Educ Q 1987;14(1):11-25.

3 Barry B. Why social justice matters. Cambridge UK: Polity Press, 2005.

4 Schmidt H. Just health responsibility. J Med Ethics 2009;35(1):21-6.
5 Turoldo F. Responsibility as an ethical framework for public health interventions. Am J Public Health 2009;99(7):1197-202.

6 Segall S. Health, luck, and justice. NJ: Princeton University Press, 2009.

7 Feiring E. Lifestyle, responsibility and justice. J Med Ethics 2008;34(1):33-6.

8 Vincent NA. A structured taxonomy of responsibility concepts. In: Vincent NA, Poel vande I, van den Hoven J, eds. Moral responsibility: beyond free will and determinism. Dordrecht: Springer Netherlands, 2011: 15-35.

9 Schmidt H. Personal responsibility in the NHS constitution and the social determinants of health approach: competitive or complementary? Health Econ Policy Law 2009;4(Pt 2):129-38.

10 Schmidt H. Personal responsibility for health. Developments under the German Healthcare Reform 2007. Eur J Health Law 2007;14(3):241-50.

11 Schmidt H, Voigt K, Wikler D. Carrots, sticks, and health care reform — problems with wellness incentives. N Engl J Med 2010;362(2):e3.

12 Bishop G, Brodkey AC. Personal responsibility and physician responsibility — West Virginia's Medicaid plan. N Engl J Med 2006;355(8):756-8.

13 Michailakis D, Schirmer W. Agents of their health? How the Swedish welfare state introduces expectations of individual responsibility. Sociol Health IIIn 2010;32(6):930-47.

14 Adams J, Mytton O, White M, et al. Why are some population interventions for diet and obesity more equitable and effective than others? The role of individual agency. PLoS Med 2016;13(4):e1001990.

15 Pillutla V, Maslen H, Savulescu J. Rationing elective surgery for smokers and obese patients: responsibility or prognosis? BMC Med Ethics 2018;19(1):28.

16 Schirmer W, Michailakis D. The responsibility principle. Contradictions of prioritysetting in Swedish healthcare. Acta Sociol 2011;54(3):267-82

17 Saltman RB. Health sector solidarity: a core European value but with broadly varying content. Isr J Health Policy Res 2015:4(1):5.

18 Raz AE. Applying the theoretical tools: being affected, responsibility, and risk. In: Raz $A E$, Schicktanz S, eds. Comparative empirical bioethics: dilemmas of genetic testing and euthanasia in Israel and Germany. SpringerBriefs in ethics. Springer International Publishing, 2016: 21-43.

19 Schicktanz S. Genetic risk and responsibility: reflections on a complex relationship. $J$ Risk Res 2016:1-23.

20 Wikler D. Personal and social responsibility for health. Ethics Int Aff 2002;16(2):47-55.

21 Bærøe K, Cappelen C. Phase-dependent justification: the role of personal responsibility in fair healthcare. J Med Ethics 2015;41(10):836-40.

22 Eyal N. Luck egalitarianism, harshness, and the rule of rescue. In: Liao SM, O'Neil C, eds. Current controversies in bioethics. New York: Routledge, 2017.

23 Eshleman A. Moral responsibility. In: Zalta EN, ed. The Stanford encyclopedia of philosophy. Winter 2016 Edition: The Metaphysics Research Lab, 2016.

24 Daniels N. Individual and social responsibility for health. In: Knight C, Stemplowska Z, eds. Responsibility and distributive justice. Oxford Scholarship Online, 2011.

25 Resnik DB. Responsibility for health: personal, social, and environmental. J Med Ethics 2007;33(8):444-5.

26 Daniels N. Just health: meeting health needs fairly. New York: Cambridge University Press, 2008.

27 Elster J. Local justice: how institutions allocate scarce goods and necessary burdens. Russell Sage Foundation, 1992.

28 Dworkin G. Taking risks, assessing responsibility. Hastings Cent Rep 1981;11(5):26-31.

29 Golan 0. The right to treatment for self-inflicted conditions. J Med Ethics 2010:36(11):683-6.

30 Cappelen AW, Norheim OF. Responsibility, fairness and rationing in health care. Health Policy 2006;76(3):312-9.

31 Voigt K. Appeals to individual responsibility for health. Camb Q Healthc Ethics 2013;22(2):146-58.

32 Vincent NA. What do you mean I should take responsibility for my own ill health? J Appl Ethics Philos 2009;1:39-51.

33 Owen-Smith A, Coast J, Donovan Jenny L. Self-responsibility, rationing and treatment decision making - managing moral narratives alongside fiscal reality in the obesity surgery clinic. Health Expect 2018.

34 Lippert-Rasmussen KJ. (Luck and relational) egalitarians of the world, unite! In: Sobel D, Vallentyne P, Wall S, eds. Oxford studies in political philosophy. . Oxford University Press, 2018: 4. 81-109.

35 Albertsen A. Personal responsibility in oral health: ethical considerations. J Forensic Odontostomatol 2012;30:12-20.

36 Scanlon TM. Responsibility and the value of choice. Think 2013;12(33):9-16.

37 Segall S. What's so egalitarian about luck egalitarianism? Ratio 2015;28(3):349-68.

38 Buyx AM. Personal responsibility for health as a rationing criterion: why we don't like it and why maybe we should. J Med Ethics 2008;34(12):871-4.

39 Lippert-Rasmussen KJ. Democratic egalitarianism versus luck egalitarianism: what is at stake? Philos Topics 2012;40(1):117-34.

40 Brandt RB. Morality, utilitarianism, and rights. US: Cambridge University Press, 1992.

41 Cappelen AW, Norheim OF. Responsibility in health care: a liberal egalitarian approach. J Med Ethics 2005;31(8):476-80.

42 Sharkey K, Gillam L. Should patients with self-inflicted illness receive lower priority in access to healthcare resources? Mapping out the debate. J Med Ethics 2010;36(11):661-5.

43 Marmot M, Bell R. Social inequalities in health: a proper concern of epidemiology. Ann Epidemiol 2016;26(4):238-40. 
44 Leisman G, Machado C, Melillo R, et al. Intentionality and "free-will" from a neurodevelopmental perspective. Front Integr Neurosci 2012;6(36):36.

45 Minkler M. Personal responsibility for health? A review of the arguments and the evidence at century's end. Health Educ Behav 1999;26(1):121-41.

46 Brownell KD. Personal responsibility and control over our bodies: when expectation exceeds reality. Health Psychol 1991;10(5):303-10.

47 Albertsen A, Knight C. A framework for luck egalitarianism in health and healthcare. J Med Ethics 2015;41(2):165-9.

48 Bowen GA. Document analysis as a qualitative research method. Qual Res $J$ 2009;9(2):27-40.

49 Green J, Thorogood N. Qualitative methods for health research. SAGE, 2018.

50 Hatland A, Kuhnle S, Romøren TI. Den norske velferdsstaten. Oslo: Gyldendal Akademisk, 2007

51 Pasient- og brukerrettighetsloven. 1999. Lov om pasient- og brukerrettigheter m.v. av 1999-07-02 nr 63. Available: https://lovdata.no/dokument/NL/lov/1999-07-02-63

52 Spesialisthelsetjenesteloven. 1999. Lov om spesialisthelsetjenesten m.m. av 1999-07$02 \mathrm{nr} 61$. Available: https://lovdata.no/dokument/NL/lov/1999-07-02-61

53 Innvaer S. The use of evidence in public governmental reports on health policy: an analysis of 17 Norwegian official reports (NOU). BMC Health Serv Res 2009;9(1):177.

54 Christensen J, Holst C. Advisory commissions, academic expertise and democratic legitimacy: the case of Norway. Sci Publ Policy 2017;44(6):821-33.

55 NOU 1997:7. Piller, prioritering og politikk. Hva slags refunsjonsordning trenger pasienter og samfunn? Oslo: Statens forvaltningstjeneste, 1997.

56 St. Meld nr. 41 (1987-1988). Helsepolitikken mot år 2000. Nasjonal helseplan. Oslo: Sosialdepartementet, 1988
57 NOU 1997:18. Prioritering på ny - gjennomgang av retningslinjer for prioritering innen norsk helsetjeneste. Oslo: Statens forvaltningstjeneste, 1997.

58 NOU 2000:2. Behandlingsreiser til utlandet — Et offentlig ansvar? Oslo: Statens forvaltningstjeneste, 2000

59 Meld. St. 34 (2015-2016). Verdier i pasientens helsetjeneste — Melding om prioritering. Oslo: Helse- og omsorgsdepartementet, 2016

60 NOU 1987:23. Retningslinjer for prioriteringer innen norsk helsetjeneste. Oslo: Statens forvaltningstjeneste, 1987.

61 St. Meld nr. 44 (1989-1990). Egenbetaling i helse- og sosialtjenesten. Oslo: Statens forvaltningstjeneste, 1990.

62 St. Meld. nr. 50 (1993-94). Samarbeid og styring - Mål og virkemidler for en bedre helsetjeneste. Statens forvaltningstjeneste, 1994.

63 NOU 2018: 16. Det viktigste først - Prinsipper for prioritering i den kommunale helseog omsorgstjenesten og for offentlig finansierte tannhelsetjenester. Oslo: Statens forvaltningstjeneste, 2018.

64 NOU 2014:12. Appent og rettferdig - prioriteringer i helsetjenesten Norges offentlige utredninger. Oslo: Statens forvaltningstjeneste, 2014.

65 Helse- og omsorgsdepartementet. På ramme alvor. Alvorlighet og prioritering. Rapport fra arbeidsgruppe nedsatt av Helse- og omsorgsdepartementet. Oslo, 2015.

66 Hill TE. How clinicians make (or avoid) moral judgments of patients: implications of the evidence for relationships and research. Philos Ethics Humanit Med 2010;5.

67 Brudney D. Are alcoholics less deserving of liver transplants? Hastings Cent Rep 2007;37(1):41-7. 